\title{
Virtual Network for Diamond Supply Chain in Thailand
}

\author{
Duangpun Kritchanchai* \\ Department of Industrial Engineering \\ Mahidol university, Nakhonpathom,73170, Thailand \\ E-mail: egdkc@mahidol.ac.th* \\ Tuanjai Somboonwiwat \\ Department of Industrial Engineering \\ King Mongkut's University of Technology Thonburi, Bangkok, 10140, Thailand \\ Tel (662)470-9171,E-mail: tuanjai.som@kmutt.ac.th
}

\begin{abstract}
Gems and Jewelry industry is one of the growing industries in Thailand. Not less than 17.7\% of the exporting value from this industry is from diamond. Approximately $70 \%$ of total exporting diamonds are polished diamond. With the reputation of "Bangkok Cut", the exporting rate seems to grow rapidly. However while we enjoy the export growth of these gems, the value add to diamond jewelry is still low. An attempt is made in this study to investigate the whole supply chain from rough cut diamond to polished diamond and to diamond jewelry. The diamond supply chain is modeled by SCOR model. Problems in the chain are reflected. It is found that Thailand has a potential to become the diamond exchange centre of the region. Surprisingly, the idea of value chain for gems to jewelry cannot be achieved. Instead, we test the solution of Virtual supply chain via E-marketplace. The architecture of this virtual exchange network is proposed. The strategy enforcing this network is then positioned.
\end{abstract}

Keywords: ogems and jewelry, diamond, supply chain

\section{Introduction}

Lambert and Cooper (2000) stated that supply chain management is a new way of managing the business and its relationship. They believe in network structure, the information and product flows and the key supply chain business processes instead of functional silos within the company or across the supply chain. Key trends which have been identified include "cooperation" rather than "competition" (Storey et al. 2006). Balakrishan and Geunes (2004) also supports that the trend towards the conscious examination and rationalization of supplier networks and the development of "collaborative" or "partnership" relationships between buyers and suppliers must be focused. Tan (2001) referred to supply chain as it encompasses the entire value chain

\footnotetext{
*Corresponding Author
}

and addresses materials and supply management from the extraction of raw materials to its end of useful life. He also highlighted that supply chain management appears to treat all organizations within the value chain as a unified "virtual business" entity.

The study here focuses on supply chain management and the relationships in diamond industry from sources, diamond factory and jewelry factory. Diamond is one of the important export products in Thailand (The gem and jewelry institute of Thailand 2008). Raw materials, rough diamond, are all imported to be polished and then exported. Some polished diamonds are imported for the jewelry industry and then the diamond jewelry supplies to local and export market. Having realized 
the importance of collaborations in supply chain and the trends of value chain, our attempt has been made to develop the linkage in supply chain of overall diamond industry processes. Two research questions are raised.

1) Can value creating activities be possibly made in Thailand diamond value chain?

2) Which model of collaborative supply chain is suitable for diamond industry in Thailand?

To address the first question, overall activities in the chain must be investigated. Here, SCOR model is applied. The collaborative model by virtual business network is proposed. Information technology by E-marketplace is designed and discussed in order to address the second question.

\section{Literature Review}

Social Research Institute of Chiang Mai University (2002) had studied gems and jewelry branch in Thailand. The purpose is to specify ways for gems and jewelry industry development in the next 10 years. They recommended the development and trade opportunity between countries particularly on functions of private and government sector. Leelakawewong (2002) studied the problems and situations of SMEs in jewelry industry. The study found that they must create knowledge center for gem and jewelry industry development. The centre should comprise of knowledge compilation sources, creating database, training employees and creating new knowledge. He proposed a policy "Strategic alliance and network" between or in SME groups. He also stated that investment for research and development is essential for technology capability development.

Research center at the Sasin Graduate Institute of Business Administration at Chulalongkorn University (1999) had studied the strategy to increase marketing capability of gems and jewelry industry. The study found that to increase marketing capability of gem and jewelry industry must be planned as short, medium and long terms. The short term strategy indicated that all sizes of gems and jewelry entrepreneur database must be created for business matching between sellers and buyers. It should also create marketing manual, investment manual, SME support and labor and design development. Next strategy is medium strategy which is between 2 to 5 years. The plan is to create gems and jewelry mart within the country. Also a Thai brand must be created. Gem centre of each region with distribution center in destination countries must also be initiated. The long term strategy which is over 5 years stated that we should develop raw material sources in Thailand. The plan should support exporters to use Thai brand with a program of continuous improvement for the local manufacturers.

The above literatures propose ways to enhance competitive advantage of this industry in Thailand. Most of them believe that while improving internal capabilities of this industry, marketing factors must also be taken into account. Apart from the literatures above, we also found group of literatures stating the idea of cyberspace marketing.

Online Sourcing Project (ospgemsjewelry.com) is a website of The Thai Gems and Jewelry Traders association. The website contains a number of mini websites which are owned by members. The webmasters bring information to those who wish to do business matching. Then, they arrange schedule to set up member meeting requested.

Jewelry Trade Center (jewelrytradecenter.com) is another Thai website belonging to Silom Galleria. The products offered are all types of gem stones and valuable metals such as gold, silver, platinum, etc. The main purpose of this website is for selling and buying. All products offered here are qualified by well known certificates.

Myjewellerywarehouse.com is an E-marketplace website which has just opened since 2008. This website is similar to the Jewelrytradecenter.com with a special function of photo attaching.

Tiffany \& Co. (www.tiffany.com) is a United State's website. This website is also offering selling and buying gems and jewelry. Customers can fill in their requirements and the system will offer all products that meet the requests. All products here come with quality certificates. These can be summarized in Table 1.

After reviewing all above practical trends, it is realized that virtual network which provides platform for all supply chain players has taken the place. It would enable companies to manage their supply chain on a global scale. The integration of internal and external supply chain activities will be strengthened via information technology system. However, in Thailand settings, the physical linkage between overall processes in supply chain must be 
Table 1. Practical trends in gem and jewelry industry

\begin{tabular}{|l|l|}
\hline \multicolumn{1}{|c|}{ Cases } & \multicolumn{1}{|c|}{ Needs and Trends } \\
\hline Social Research Institute (2002) & Trade opportunities between countries \\
\hline Leelakawewong (2002) & $\begin{array}{l}\text { - Knowledge centre for gem and jewelry } \\
\text { industry } \\
\text { - Strategic alliance and network }\end{array}$ \\
\hline $\begin{array}{l}\text { Sasin Graduate Institute of } \\
\text { Business Administration (1999) }\end{array}$ & $\begin{array}{l}\text { Gems and jewelry database for business } \\
\text { matching }\end{array}$ \\
\hline $\begin{array}{l}\text { Online Sourcing Project (0SP) } \\
\text { (www.ospgemsjewelry.com) }\end{array}$ & Business matching \\
\hline $\begin{array}{l}\text { Jewelry Trade Center Bangkok } \\
\text { (www.jewelrytradecenter.com) }\end{array}$ & E-marketplace \\
\hline $\begin{array}{l}\text { Myjewellerywarehouse } \\
\text { (www.myjewellerywarehouse.com) }\end{array}$ & E-marketplace \\
\hline \begin{tabular}{l} 
Tiffany \& Co. (www.tiffany.com) \\
\hline
\end{tabular} & Selling and buying website \\
\hline
\end{tabular}

synchronized as the first step. The connection of chain between gems and jewelry must be encouraged. Value chain is our ultimate goal. Seamless supply chain within the country is expected. Thus, in this study, we investigate the diamond and jewelry supply chain with the problems to be highlighted.

\section{Research Methodology}

This research focuses on the development of Thailand's diamond industry. This study is to investigate capabilities of diamond and jewelry supply chain and help create coordinations between supply chain both inside and outside the country.

Firstly, we begin with collecting problem details by study the whole supply chain. An in-depth interview is conducted with manufacturers and traders. This is to investigate the current situation of the diamond jewelry manufacturing industry. This starts from raw material to jewelry factory. An attempt is made to model the supply chain based on SCOR model. The analysis is made based on SWOT analysis.

Secondly, a focus group is set to confirm all the problems found. A solution for creating supply chain is proposed. All elements are designed with respect to the problems identified. Then the model for this Thailand diamond and jewelry supply chain is designed.

\section{Current Situations of Diamond Jewelry Industry in Thailand}

The major source of diamond supplier in the world is from "De Beers". They have power to control the whole market and be able to define price and their member suppliers. This is called "sight holder". De Beers has around 84 sight holders around the world. These sight holders buy diamonds from De Beers and sales them to manufacturers. Thailand once has been their sight holder but when the membership fee increases, the membership was terminated. We then can only be an OEM for De Beers's sight holders.

Diamond industry in Thailand used to cut small diamond and supply to medium grade market. However China and India had become a great competitor as they produce at a very low price. Thai diamond had to move up to a higher grade and cut bigger size of diamond. We tried to create a unique style of cutting which is called "heart and arrow". This has been very successful in a hi-end market.

Nevertheless, we still face many difficulties in this industry. Obviously, lack of raw material is a very major concern. Also, equipment and technology becomes very significant for improving the cutting design. Since we supply $80 \%$ of cut diamond to overseas market, exporting factors including competitors are our barriers.

In China, they strongly promote diamond exchange centre in Shanghai. They have large amount of labour in this industry as well as big domestic market. In India, low labour cost brings them very attractive in cutting for mass market. In Belgium, the import tax for gems and jewelry reduce to $0-0.4 \%$ whereas in Thailand VAT is still applicable. We then summarise all these situations and analyse by SWOT analysis in Table 2.

Table 2 shows the analysis of big picture in this industry in Thailand. After this, an interview was conducted. The interview results enable us to structure the supply chain of diamond industry in Thailand. Figure 1 illustrates the structure of diamond supply chain.

At the upstream player, rough diamonds are imported via De Beers or middle man. In midstream process, it is then cut and polished in manufacturers in Thailand. $90 \%$ of this polished diamonds are 
Table 2. SWOT Analysis of the diamond industry in Thailand

\begin{tabular}{|c|c|}
\hline \multicolumn{2}{|c|}{ Internal Environments } \\
\hline Strengths & Weaknesses \\
\hline $\begin{array}{l}\text { 1. High quality in cutting diamonds such as Heart \& Arrow style. } \\
\text { 2. Lower labor cost than in Europe and America. } \\
\text { 3. One of tourism hubs in Asia. } \\
\text { 4. A free trade country which regulations and rules are worldwide } \\
\text { acknowledged. }\end{array}$ & $\begin{array}{l}\text { 1. } 100 \% \text { of Rough diamond needs to be imported. } \\
\text { 2. Comparing to China or India, labor cost is higher. } \\
\text { 3. Lack of skilled and experienced labors. } \\
\text { 4. Lack of skills in jewelry design. } \\
\text { 5. Lack of effective coordination between government agencies and } \\
\text { private sectors. } \\
\text { 6. Lack of marketing network. }\end{array}$ \\
\hline \multicolumn{2}{|c|}{ External Environments } \\
\hline Opportunities & Threats \\
\hline $\begin{array}{l}\text { 1. The Geography of Thailand is suitable to be a world diamond exchange } \\
\text { center as it is not far from manufacturers and rough diamond sources. } \\
\text { 2. Thai cultural and tradition are unique and famous. } \\
\text { 3. There are opportunities to make Thai brands by developing our unique } \\
\text { style of cutting. } \\
\text { 4. Thailand is well known as a center for color gems exchange. }\end{array}$ & $\begin{array}{l}\text { 1. VAT is still applicable. } \\
\text { 2. China and India become significant competitors. } \\
\text { 3. } 90-95 \% \text { of the Thai diamond competes in the same market as China and } \\
\text { India. } \\
\text { 4. World economic recession. }\end{array}$ \\
\hline
\end{tabular}

exported to hi-end market. The rest of that are supplied domestic to wholesale and retail shops. Some of them are supplied to jewelry factory in the country.

\section{An Analysis by SCOR Model}

From Table 2 and Figure 1 above, we then use a process model by referring to SCOR Model (The Supply Chain Council 2007). The model shows current processes which consist of planning process
(Plan), rough diamond sourcing (Source), production (both cut and facet) (Make) and delivery (Deliver). The SCOR Model level 1 of the diamond industry by process reference model illustrates the rough diamond procurement planning (Plan source), purchasing rough diamonds (Source), cutting or faceting planning (Plan make), diamond cutting or faceting (Make), delivery planning for polished diamond (Plan deliver), and polished diamond delivery (Deliver). These processes can be written in SCOR level 1 model in Figure 2.

Figure 1. Structure of diamond supply chain in Thailand

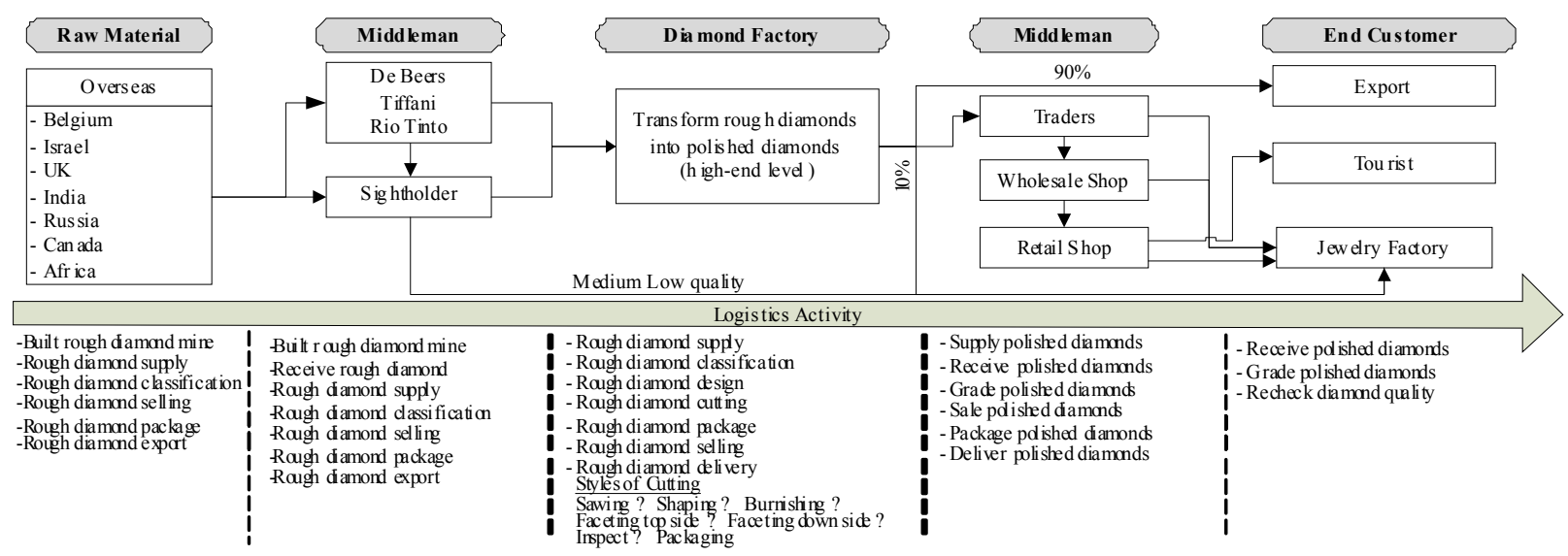


Figure 2. SCOR Model level 1 of the diamond industry in Thailand

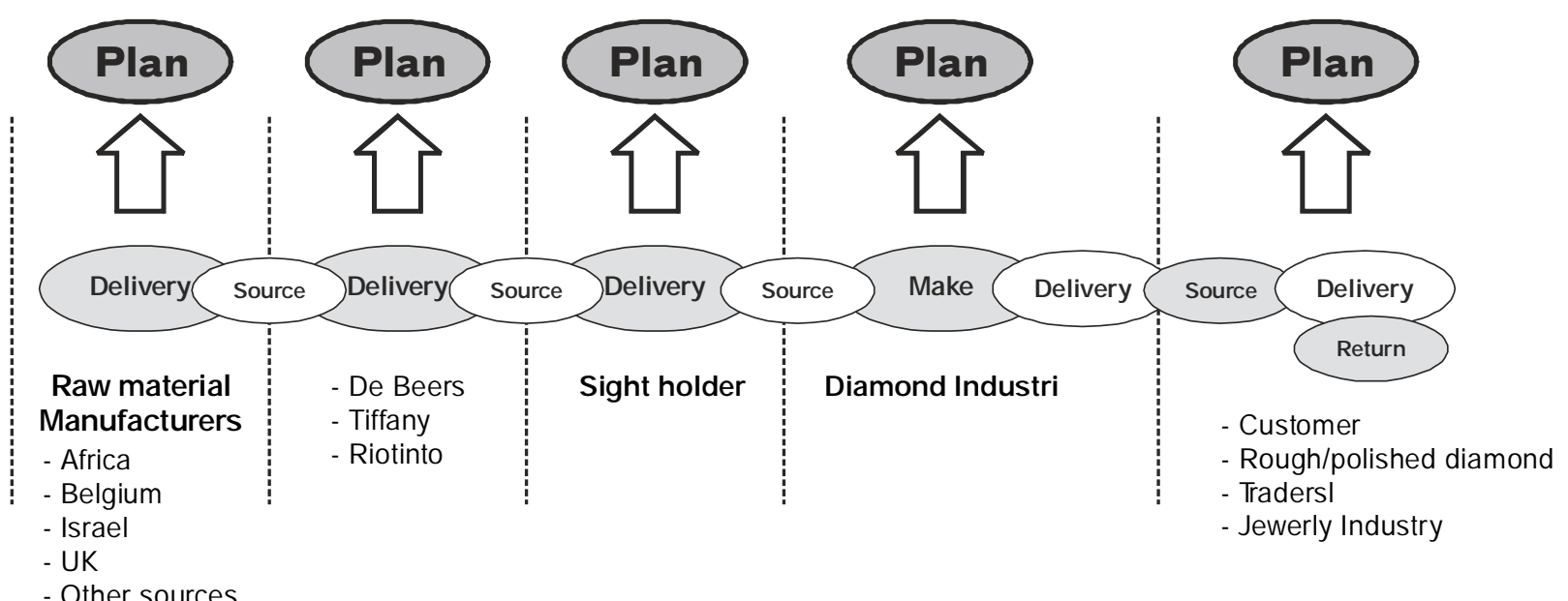

Table 3. Guidelines for applying IT to solve gems and jewelry problems

\begin{tabular}{|c|c|c|}
\hline Problems & Causes & IT Function/Approach Analysis \\
\hline $\begin{array}{l}\text { 1. Lack of raw materials and } \\
\text { cooperation of entrepreneurs } \\
\text { in diamond industry. }\end{array}$ & $\begin{array}{l}\text { Lack of raw material sources. As } \\
\text { financial limitation of Thai } \\
\text { entrepreneurs, Thailand was not } \\
\text { chosen to be a sight holder of De } \\
\text { Beers. Therefore, we need to source } \\
\text { from open-market. }\end{array}$ & $\begin{array}{l}\text { E-Business Matching } \\
\text { - Create a database of raw material sources by collecting requests from the manufacturers } \\
\text { - Link to database and important resources for raw material sourcing } \\
\text { - Provide business matching between raw material sources and Thai manufacturers. } \\
\text { E-Purchasing } \\
\text { - There should be a database for collecting orders from manufacturers. } \\
\text { - As prices often changed, updating should always be done. }\end{array}$ \\
\hline $\begin{array}{l}\text { 2. Lack the effective financial } \\
\text { transaction and loan } \\
\text { resources (GEM BANK) of } \\
\text { jewelry entrepreneurs }\end{array}$ & $\begin{array}{l}\text { Thailand lacks of financial electronic } \\
\text { database and lacks of intermediaries } \\
\text { to receive payments from customers } \\
\text { through intermediaries to the } \\
\text { operators. }\end{array}$ & $\begin{array}{l}\text { E-Finance } \\
\text { - Offer services through online banking and Tele Banking. } \\
\text { - Collect and analyze important financial information. } \\
\text { - Create a database for financial information and measures for important finance. } \\
\text { Provide suggestion about important financial sources such as Total Information Guidance Center and } \\
\text { websites of financial institutions. } \\
\text { - One-stop Service for financial transactions. } \\
\text { - As a middleman for payments so it is able to sell products to whomever worldwide and payments will } \\
\text { be in e-currency. }\end{array}$ \\
\hline $\begin{array}{l}\text { 3. Lack of information presentation } \\
\text { in terms of prices and quality } \\
\text { comparing. The buyer may not } \\
\text { be able to decide immediately. If } \\
\text { there is no data to compare } \\
\text { price and quality. }\end{array}$ & $\begin{array}{l}\text { The buyer may not be able to decide } \\
\text { immediately. If there is no data to } \\
\text { compare price and quality. }\end{array}$ & $\begin{array}{l}\text { E-Catalog } \\
\text { - Associate with transportation companies (Shipping). } \\
\text { - There are system for providing price offering (quotation) and for comparing products (price and quality) } \\
\text { - Collecting information about designs/styles of diamonds and jewelry. } \\
\text { - Provide product incentive such as presenting product and service online and providing promotion via } \\
\text { customers' e-mail. }\end{array}$ \\
\hline $\begin{array}{l}\text { 4. Lack of systematically } \\
\text { resources and ability of trace } \\
\text { back each product. }\end{array}$ & $\begin{array}{l}\text { - Public relation is unclear and cannot } \\
\text { check for what status of product is } \\
\text { and how many days the products will } \\
\text { reach customer sites. These cause } \\
\text { ineffectiveness in providing } \\
\text { information to customers. } \\
\text { - There are many websites providing } \\
\text { information about gems and jewelry. } \\
\text { However, those websites belong to } \\
\text { different organizations or agencies } \\
\text { which cause information to be } \\
\text { scattered. }\end{array}$ & $\begin{array}{l}\text { E-Information. } \\
\text { - There is an activity calendar. Visitors can apply to attend through e-mail. } \\
\text { - Create a database for rough diamond, diamond production, marketing, import and export statistics. } \\
\text { - Provide a good public relation and interesting issues to attract investors or diamond traders to visit } \\
\text { the website and magnetize manufacturers to invest in Thailand. } \\
\text { - Link to news websites classified by category and research work and users can search for news by } \\
\text { using a key word or time period. } \\
\text { - Provide an enquiry option where users can leave their comments about products on the web-board. } \\
\text { E-Member / E-Profile } \\
\text { - Be able to collect marketing information of each customer in database. } \\
\text { - Users are able to edit some part of information. } \\
\text { - Collected information will be in the database system. } \\
\text { - Link into the database between buyer and seller information such as production capacity / performance. } \\
\text { - Customer relationship management (CRM) such as customer preference, enhance customer relation } \\
\text { by offering special products and service. }\end{array}$ \\
\hline
\end{tabular}


From the SCOR model, the process of plan source and source cannot be predicted and controlled. This is because of the power of supplierDe Beers. Since we cannot predict the source, the plan source affects our production plan internally. The manufacturers cannot specify size or quality of diamonds because they are already specified by the sight holder. Therefore the plan make cannot respond well to the customer requests. This problem together with lack of skilled labor and designer are a main barrier for the development from OEM to ODM and OBM. Being only an OEM and selling back to the vendor, Thailand has no chance to connect the gems supply chain to the jewelry supply chain. This value cannot be added within the country.

Having realized all these difficulties, linking all activities in the gems and jewelry supply chain in Thailand is unlikely promising. Increasing distribution channels for enhancing market access seems to be doable. Thus an e-marketplace tends to be one of the solutions. This is hoped to enhance possibility to establish diamond exchange center in Thailand and to link together to end customers. Here we summarise problems, causes, and guideline for applying IT in gems and jewelry industry in Table 3.

\section{Thailand Diamond Exchange Online System}

To improve market access by increasing distribution channels and raw materials sourcing, those Efunctions proposed above are designed in Figure 3.

\subsection{Designing a Structure for E- Marketplace Model to Respond to Problems}

The Object-oriented analysis and design techniques are to create a model of the online marketing system of diamond industry and accessories. This shows the links between marketing management system and the database in Figure 4.

\subsubsection{System Overview}

The system and database for the Thai diamond industry are in Web Based Applications and online market websites which consist of Front-end and Back-end. In these application and websites, information and data are classified to be simple and
Figure 3. E- marketplace model of the diamond industry (Business Model).

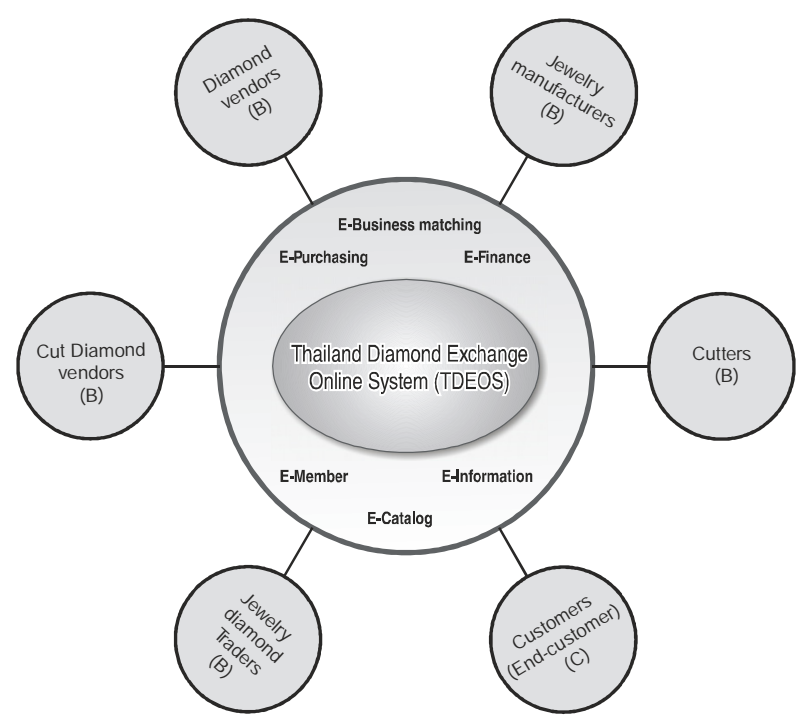

Figure 4. Database management system of Thailand diamond exchange Online System

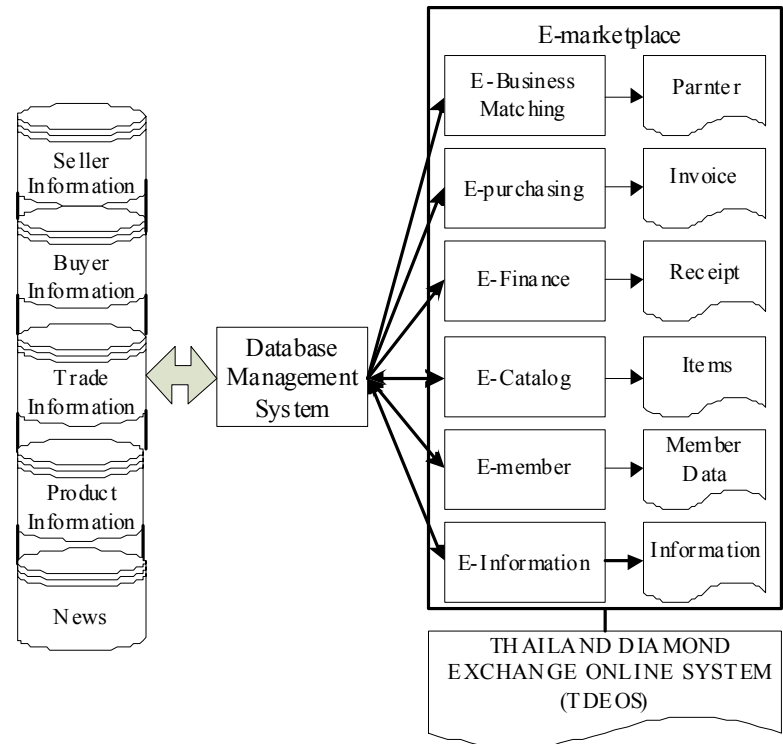

convenient to access, update and maintain. The applications and websites are in attractive format, dynamic web page with various languages, Thai, English and Chinese. In order to meet user requirements, the following functions are included. These are: 
- Business matching/raw material supply system

- Built-in search engine within the website. News and Web board System

- Efficient management and security protective system

- Online survey and comments' system

- Marketing system

- Purchasing system·Online catalog/shopping cart system

- Shopping cart system

- Entrepreneur or manufacturer databaseOnline advertising via website and automated e-mail dispatching system

\subsubsection{Business Goals}

The business goal of this system is to create a network of diamond traders in the region. The network will associate news, information, product, service, and modern money transaction channel between members. As soon as this market launches on electronic channel, the network-based location can stay on the same electronic system to do their responding transaction. The functions of each system are summarized in Table 4 .

\subsubsection{Site Map}

The Site map of E-marketplace system informs about where the websites are, which pages, and where they are linking to which page. This is to support the customers to reach all pages. It also helps the spiders of search engine as illustrated in Figure 5.

Table 4. Functions of the diamond E-marketplaces

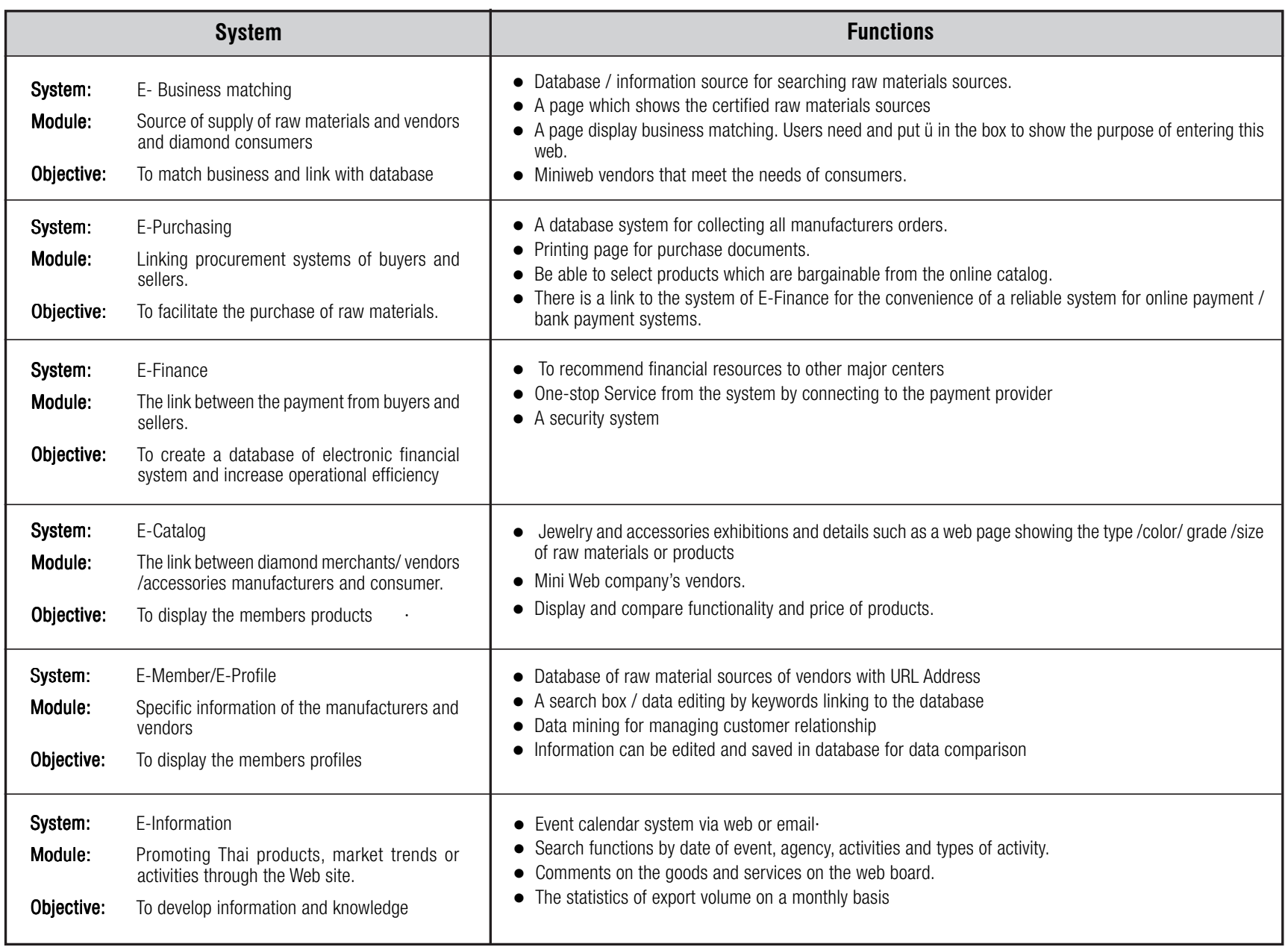


Figure 5. Site Map of the diamond exchange centre online system

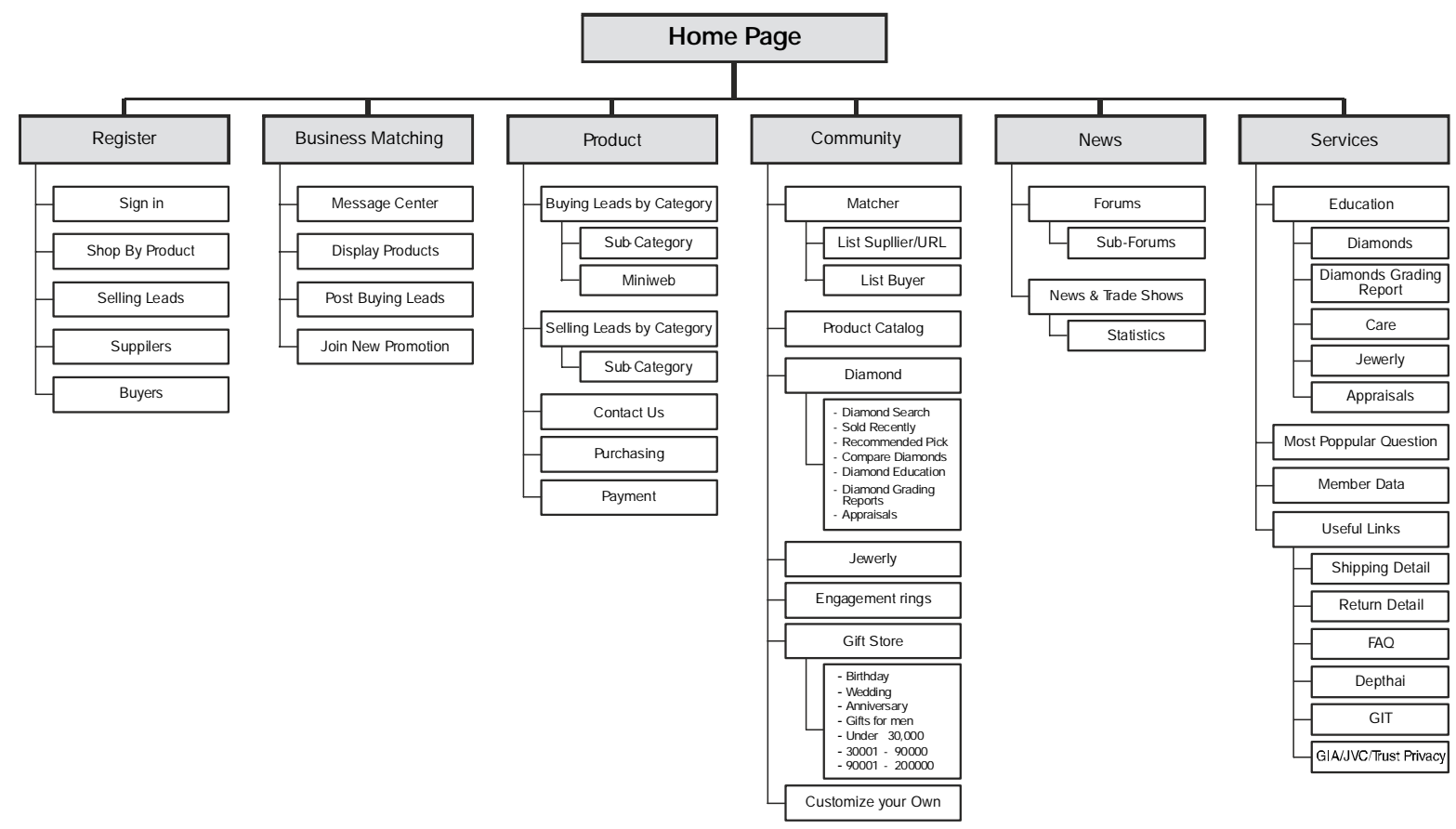

Figure 6. ER diagram of the system

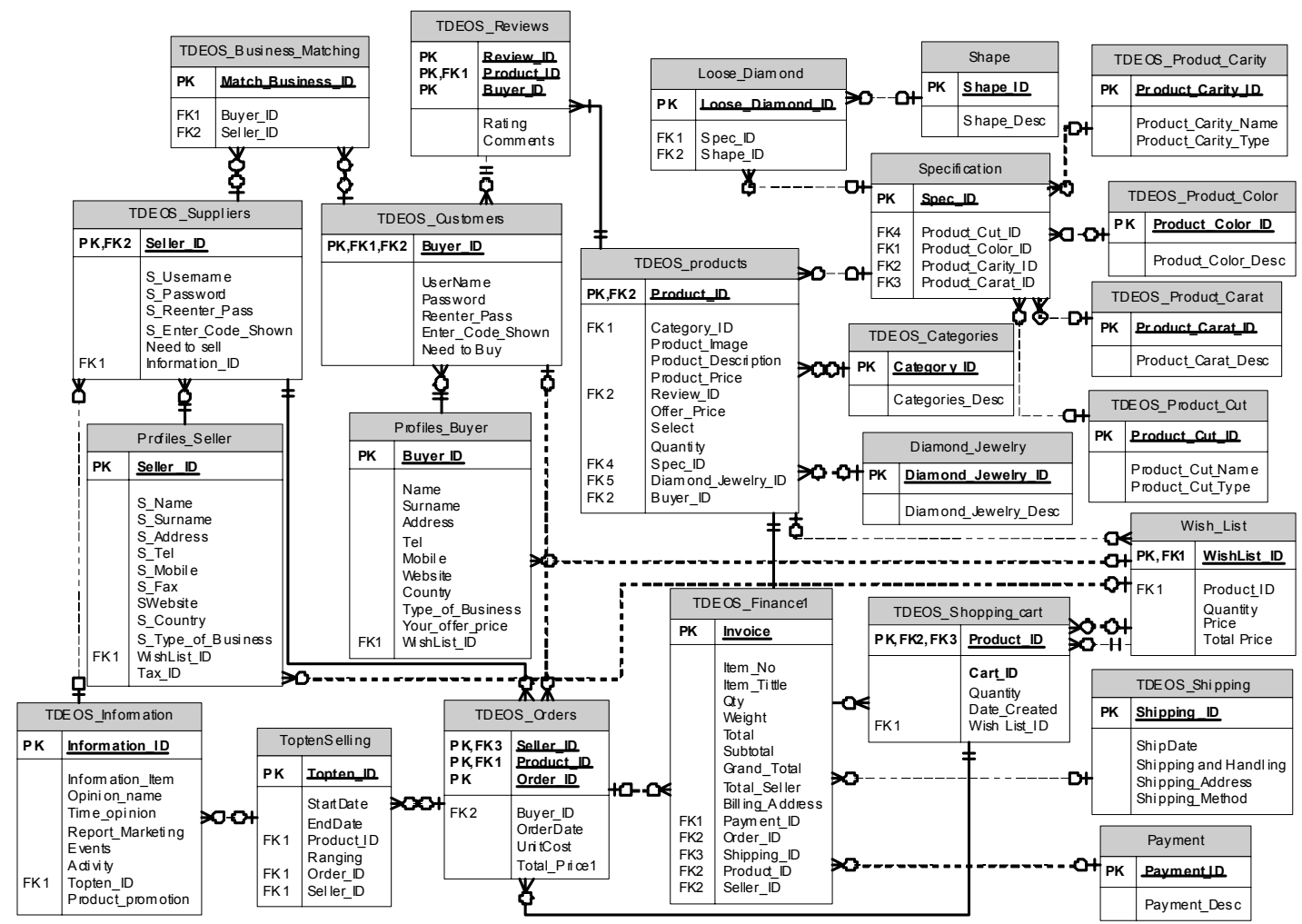




\subsection{Data Model}

The data model or information flow diagram presents relationship between process and information. The data model or ER diagram shows the relationship between information. The ER diagram consists of entity of relationship and attribute. This relationship between entities can be related to each other as one to one, one to many, or many to many as indicated in Figure 6.

\section{The Strategic Recommendations for Thailand Diamond Industry}

The proposed structure model for the e-marketplace is to enhance the marketing channels and facilitate the manufacturers at the operational level. However this idea is merely a passage to access the markets and improve market opportunities. It is realized that the real diamond exchange centre must be explicitly established and activated. The supply chain of diamond industry in Thailand must be linked especially between gems and jewelry trader. We propose that government and private sectors must be involved. This is presented in Figure 7.

Here we propose four strategic projects. Project 1 must be strongly initiated by the government. They must recognize the importance of this industry and set a strategic direction for developing a centre of trade and exchange diamond together with jewelry and accessories. Project 2 can be done by either

Figure 7. The strategic plan for supporting Thai gems and jewelry centers

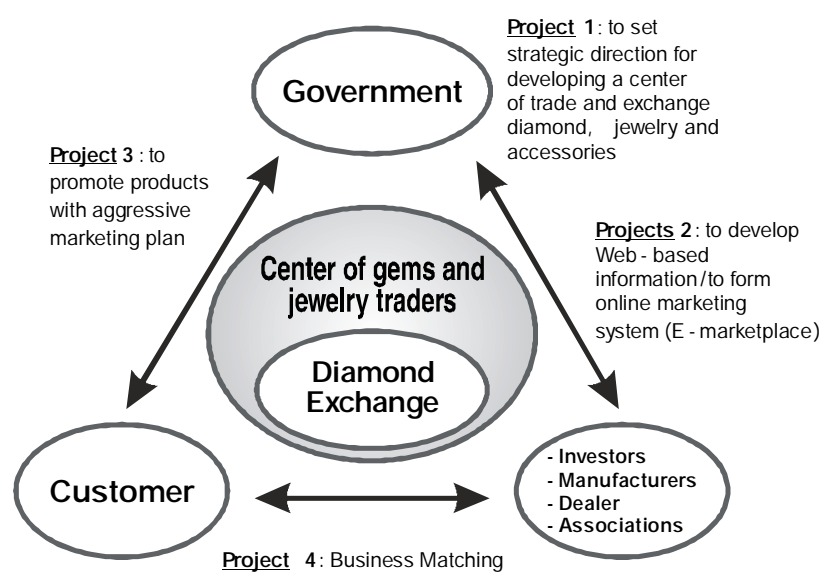

government or private sector. This is to enable the web based information and form online marketing system as proposed in this study. Project 3 is to promote Thailand products with its brand. This can be done by gems and jewelry associations with a support from the government. Finally project 4 is to encourage the business matching between customer and manufacturers, dealer and any investors. This can be done via the e-marketplace among the private sectors.

\section{Discussion and Conclusion}

This study explores in-depth the diamond and jewelry supply chain in Thailand. SCOR model has been applied to reflect the linkage of each player in the chain. It is found that the root cause problem for diamond supply chain in Thailand is lack of raw material. This is because of the power of world dominated supplier. Therefore plan source activity is difficult, affecting the plan make. Thus the idea of creating the supply chain and value chain within the country is hard to achieve. Gems industry's production plan cannot be connected with the jewelry production plan.

The only connecting point must be to offer those traders and manufacturers the open market. They all must expose to all sources of suppliers. The idea of "many to many" leads us to develop an emarketplace which information technology plays their role. This enables both gems and jewelry to meet within and across industry. Hence the Thailand Diamond exchange online system is then developed. Seven IT Functional systems are proposed. These are the E-Business Matching, E-Finance, E-Marketing, E-Purchasing, E-Catalog, E-Profile/ E-Member and E-Information. They are operated on web-base application in the E-Marketplace.

Being situated as a land-linked between East and West in the region, together with high reputation in diamond cutting, Thailand has a potential to be hub of gems and jewelry trading centre. However, the findings are evident that virtual network is preferred while the physical supply chain cannot be effectively connected. Operating this e-marketplace is the first step for increasing opportunities to expose the markets both upstream and downstream. This must be strengthened by the country policy and actions from both government and private sector to establish 
a real diamond exchange centre. Having designed this virtual supply chain network via information technology, it is hoped that the problem of supplier sources will be eliminated. This also helps connecting the linkage in the chain and facilitates this industry to become sustain in the future.

\section{References}

Balakrishan, A. and Geunes, J. (2004). Collaboration and coordination in supply chain management and ecommerce, Production and Operations Management, 13(1), pp. 1-2.

Jewelry TradeCenterBangkok.(2009). “www.jewelrytradecenter.com”.

Lambert D.M. and Cooper, M.C. (2000). Issues in Supply Chain Management, Industrial Marketing Management 29, pp. 65-83

Leelakawewong, W. (2002). Final Report: The Study of Problem, Status and Evaluation of Capability of SME in Silver $\mathcal{E}$ Gold Jewelry Industry. Thailand Research Fund.

Myjewellerywarehouse. (2009). "www.myjewellerywarehouse.com". OnlineSourcingProject(OSP).(2009). “www.ospgemsjewelry.com”.
Research Center at the Sasin Graduate Institute of Business Administration at Chulalongkorn University. (1999). Final Report: The Marketing Competitive Strategy of Gem and Jewelry Industry. Thailand Research Fund.

Social Research Institute of Chiang Mai University. (2002). Master Plan for Gem and Jewelry Industry (10 years). The Office of Industrial Economics.

Storey, J., Emberson, C., Godsell, J., and Harrison, A. (2006). Supply chain management: theory, practice and future challenges, International Journal of Operations \& Production Management, 26(7), pp. 754774.

Tan, K.C. (2001). A framework of supply chain management literature, European Journal of Purchasing $\mathcal{E}$ Supply Management, 7: 39-48.

The gem and jewelry institute of Thailand (Public Organization). (2008). Thailand's Gems and Jewelry Import and Export Performance in 2007, GIT Trade Review Information Center Issue 1/2008.

The Supply Chain Council. (2007). The supply chain Operations Reference model (SCOR), from http:// www.supply-chain.org/html/faq.htm.

Tiffany \& Co. (2009). “www.tiffany.com”.

Duangpun Kritchanchai, Ph.D. was engaged as the project leader for several large-scale projects such as the Supply-chain management project for SMEs and the Logistics policy for Rubber supply chain, Thailand Research Fund. Her research interests are in supply chain management, information technology in logistics and supply chain, healthcare supply chain. She is currently serving at Mahidol University, in the capacity of Associate Professor and Director in the Centre of Logistics management, as well as holding the position of Coordinating Chair of Logistics Research Group, Thailand Research Fund. Her email address is egdkc@mahidol.ac.th.

Tuanjai Somboonwiwat, Ph.D. is an Assistant Professor in the Industrial Management section, Department of Production Engineering, Faculty of Engineering, King's Mongkut University of Technology Thonburi, Thailand. She received her M.Eng. in Industrial Engineering from Chulalongkhorn University,Thailand and Ph.D. in Industrial Engineering from Corvallis, Oregon State University, USA. Her research interests include logistics and supply chain management, business process and applications of operations research. Her email address is tuanjai.som@kmutt.ac.th. 